\title{
Recognition of Political Rights of Persons with Disabilities at the Election of Mayor and Vice Mayor of Pekanbaru Year 2017
}

\author{
Dina Lestari ${ }^{1}$, Baskoro Wicaksono ${ }^{1}$, Ishak ${ }^{1}$ \\ $\underline{\text { dinalestari913@yahoo.co.id }} \underline{1}$ \} \\ Universitas Riau $^{1}$
}

\begin{abstract}
Every citizen has the right to be actively involved in political life. Neither is the case with persons with disabilities. As a part of Indonesian citizens with disabilities are also entitled to be actively involved in political life. For the sake of achieving the fulfillment of political rights in Indonesian politics, especially in the General Election (Election), it is necessary Recognition (Recognition). Recognition (Recognition) is vital and needs to be done so that the existence is really acknowledged in the community especially in Indonesian politics. The purpose of this study is to determine the efforts undertaken by the actors involved At the election of Mayor and Vice Mayor of Pekanbaru Year 2017. This research type is descriptive with qualitative approach. The type of research data is primary and secondary data. Data collection techniques in this study are documentation and interviews. Data analysis technique is descriptive qualitative. The results show that in the framework of fulfilling the political rights In the Selection of Mayor and Vice Mayor of Pekanbaru in 2017, efforts are needed from the actors involved such as the Unitary State of the Republic of Indonesia (NKRI), the General Election Commission (KPU) of PekanbaruCity, Disability Persons Organization and Mayor and Vice Mayor of Pekanbaru in 2017. Unfortunately, not all actors show Recognition efforts on the political rights of PwDs at the election of Mayor and Vice Mayor of Pekanbaru in 2017.
\end{abstract}

Keywords: Recognition of Political Rights, Persons with Disabilities, Selection of Mayors, Deputy Mayors

\section{Introduction}

Every citizen has the right to be actively involved in political life. It is contained in various legal provisions. Similarly, with persons with disabilities as part of Indonesian citizens with disabilities are also entitled to be actively involved in political life. Persons with disabilities are entitled to equal opportunities in government, whether to vote or to be elected without discrimination. Human Rights (HAM) is a right which is owned and attached to every human being throughout his life [1]. Indeed, Human Rights are the person and nature given by the creator, the basic right that every individual possesses without exception to get it. Outlines of rights summarized in Human Rights (HAM) include political rights or known as political rights. With regard to political rights, the 1945 Constitution as the constitution of the State of the Republic of Indonesia has mandated that every citizen has the same status in law and government. 
Indonesia as a country of law recognizes and upholds Human Rights as a fundamental right that is natural. Therefore, the protection, respect and recognition of human rights, especially the recognition of the political rights of every citizen is indispensable for the achievement of prosperity and respect and justice for every citizen [2]. Recognition of political rights based on their universal nature will be successful if discrimination against the rights of a particular group or individual has been erased, for example, it has abolished discrimination against the political rights of persons with disabilities.

For the sake of the fulfillment of the political rights of PwDs, Indonesia as a state that upholds the law regulates it in various Laws and Regulations including: the Constitution of 1945, Law Number 10 Year 2016 About the Second Amendment to Law Number 1 Year 2015 On the Stipulation of Government Regulation in Lieu of Law Number 1 Year 2014 on the Election of Governors, Regents and Mayors, Law Number 8 Year 2016 on Persons with Disabilities, Regional Regulations (Perda) Riau Province No. 18 of 2013 on Protection and Empowerment of Persons Disability and Regulation of the General Election Commission (KPU) Number 14 of 2016 on the Election and Counting of Votes for the General Election of Regional Head.

In the context of General Elections (elections) the role of persons with disabilities needs special attention and utilization. However, so far they have not gained the right to have equal opportunities and treatment in order to act and act according to their conditions. Visually these people with disabilities can indeed be said to be different from the general public. But the bottom line is that the difference should not distinguish them in terms of obtaining justice and prosperity in public life, especially in Indonesian politics. It is undeniable that people with disabilities are part of Indonesian citizens. Persons with disabilities almost exist in every area of Pekanbaru City.

The physical disability of a person with disability should not prevent him from entering the government and the bureaucracy in particular to participate in the General Election. To participate in General Election (elections), persons with disabilities need to be recognized. The struggle for recognition is vital and needs to be done so that the existence of persons with disabilities is truly recognized in society especially in Indonesian politics [3], [4]. Therefore, legislation regulating the PwDs should be able to protect the political rights of PwDs, especially in the 2017 Mayor and Vice Mayor Election Pekanbaru. Based on the above description of the background, this study refers to the basic questions are: This research aims tothe efforts undertaken by the actors involved in the election of Mayor and Vice Mayor of Pekanbaru Year 2017 in accommodating the political rights of people with disability.

\section{Method}

The location of the research was conducted in Pekanbaru City. The reason the authors chose Pekanbaru City is the city of Pekanbaru is one of the areas that have the highest number of people with disability in Riau Province is 1001 people. Pekanbaru City has three times direct Mayor and Mayor Elections, After three times direct new Mayor Election in 2017 for the first time PwDs are involved in the election. This research type is descriptive with qualitative approach. The type of research data is primary and secondary data.

Data collection techniques in this study are documentation and interviews. Informants are people who are considered capable of providing information to researchers on research issues. The technique of selecting informants in this research is Purposive Sampling technique, where the selection is done deliberately based on the criteria that have been determined based on the research objectives by the researchers themselves. The informants in this study are: Chairman 
of the General Elections Commission (KPU) Pekanbaru City, Head of General Election of Finance and Logistics General Elections Commission (KPU) Pekanbaru City, Head of Access Election Center (PPUA) Disabled Riau Province, Chairman of the Center for General Elections PPUA) Persons with Disabilities Pekanbaru City, Blind People of Pekanbaru City and Persons with Tuna Daksa Kota Pekanbaru.

\section{Result and Discussion}

Persons with disabilities are anyone with longstanding physical, intellectual, mental or sensory limitations in interacting with the environment, may experience barriers and difficulties to participate fully and effectively with other citizens. As citizens, persons with disabilities have the same rights and equal treatment in the General Election (Election).

On February 15, 2017, the Regional Head General Election was held simultaneously in 101 Regions from Provincial, District and City Level. One of the regions conducting the simultaneous Regional Head Election is Pekanbaru City in order to elect the Mayor and Vice Mayor Candidate Period from 2017-2022.

\subsection{Efforts made by the General Election Commission (KPU) of Pekanbaru City in Accommodating the Political Rights of Persons with Disabilities At the Election of Mayor and Vice Mayor of Pekanbaru Year 2017}

General Election (Election) is a means of people's sovereignty held once 5 (five) Years. All parties are not only obliged to succeed the National celebration, but also need to be actively involved in realizing the implementation of qualified General Election (Election). In order to achieve a qualified General Election, the most competent General Elections (Election) according to the Law are the General Election Commission (KPU) [5], [6]. As the organizer of Mayor Election and Vice Mayor of Pekanbaru Year 2017, the General Election Commission (KPU) Pekanbaru City made efforts: (1) As part of Indonesian citizens, persons with disabilities have the right to vote and be elected in the General Election (Election). Therefore, it is appropriate for the election of Mayor and Vice Mayor of Pekanbaru in 2017 with disabilities involved in the election of Mayor and Vice Mayor of Pekanbaru Year 2017. Persecutors who are involved in the election of 141 people. (2) As mandated by Law Number 8 Year 2016 on Persons with Disabilities, one of the rights possessed by PwDs in the General Election is the right to obtain accesibility in the form of facilities and infrastructure in the election, eg coblos aids. In the Election of Mayor and Vice Mayor of Pekanbaru in 2017, the General Elections Commission (KPU) of Pekanbaru City has provided a tool for coblos for the blind (Template Braille). (3) One of the rights that people with disabilities also have in elections is the right to a political education. As the organizer of the General Elections (General Election), the General Election Commission (KPU) of Pekanbaru City has the authority to carry out socialization or political education to persons with disabilities. Political education aims to convey information about the stages and programs of elections to disability groups. Political education also aims to increase the knowledge, understanding and awareness of PwDs about elections. (4) At the time of political sosilization, the General Election Commission (KPU) of Pekanbaru City provides visual sign interpreters for the Deaf. The objective is that the persons with hearing impairment can understand and understand the material presented at the time of socialization.

In order to realize the right of PwDs in the form of the right to channel political aspiration both oral and written as well as obtaining facilities and infrastructure to provide accessibility 
in the form of facilities and infrastructure at the Election of Mayor and Vice Mayor of Pekanbaru Year 2017 Pekanbaru City Electoral Commission Asking input to disability organizations, especially the organization of the Electoral Center General Access (PPUA) Persons with Disabilities through general meetings. At the general meeting, the General Elections Commission (KPU) of Pekanbaru City asked for advice and input to the organization of the Disabled Access Center (PPUA) regarding the facilities and infrastructure needed by PwDs at the time of the election.

The many efforts made by the General Elections Commission (KPU) Pekanbaru above which is seen only the efforts of the fulfillment of the right of Tuna Daksa, the Deaf and the Blind while the efforts to fulfill the political rights of other persons with disabilities such as people with Tuna Grahita, Tuna Laras and others has not been seen done by the General Election Commission (KPU) Pekanbaru City.

3.2 Efforts undertaken by DPOs in Accommodating the Political Rights of Persons with Disabilities at the Election of Mayor and Vice Mayor of Pekanbaru in 2017

Disability organizations consist of the Indonesian Association of Persons with Disabilities (PPDI), the Indonesian Disability Women Association (HWDI), Indonesian Blind Union (PERTUNI), the Indonesian Taliban Movement (GERKATIN), the Indonesian Disabled People's Welfare Federation (FKPCTI) and specialized organizations fighting for rights The political disability of persons with disabilities in the General Election is the organization of the Disabled Access Center (PPUA). In carrying out its duties and functions to achieve an acceptable General Elections for the PwDs, the Disabled Access Center (PPUA) of the Disabled Provinces of Riau and the Disabled Access Center (PPU) of the Disabled Persons cooperates with the General Election Commission (KPU) of Pekanbaru City.

3.3 Efforts made by Mayor Candidate and Vice Mayor of Pekanbaru Year 2017 in Accommodating Political Rights of Persons with Disabilities At the Election of Mayor and Vice Mayor of Pekanbaru Year 2017

Candidate Mayor and Vice Mayor of Pekanbaru Period 2017-2022 is a candidate of Pekanbaru City leaders who will lead Pekanbaru City during the Year 2017-2022. So long as Year 2017-2022 the fate of Pekanbaru City Particularly the fate of the people of Pekanbaru City depends on the leader. As we know that Pekanbaru city community consists of various races, religions, tribes and various educational backgrounds. From a variety of religions, religions, tribes and various educational backgrounds there are people with disabilities in it. Disability residents are also part of Pekanbaru residents who need to be noticed by the candidate Mayor and Deputy Mayor especially related to political rights. Unfortunately, none of the Mayor and Deputy Mayor candidates are concerned about the rights of PwDs. So naturally if in case the disabled people feel disappointed and feel not considered by the Mayor and Vice Mayor of Pekanbaru in 2017.

The indifference of Mayor and Vice Mayor of Pekanbaru in 2017 against the rights of PwDs is visible from the vision and mis of each candidate pair. Based on the vision and mission to the 5 (five) Candidate Pairs above can be seen that In the Election of Mayor and Vice Mayor of Pekanbaru City in 2017 has not shown efforts to recognize the political rights of people with disability At the election of Mayor and Vice Mayor of Pekanbaru Year 2017. 


\section{Conclusion}

Based on the above explanation it can be concluded that the acknowledgment efforts undertaken by the actors involved in the selection of Mayor and Mayor of Pekanbaru has not been maximized.As the election organizer, the General Election Commission (KPU) of Pekanbaru City can maximize its efforts in fulfilling the political rights of PwDs not only focus on fulfilling the political rights of the blind and deaf people but the fulfillment efforts can be felt by all circles disability. As prospective leaders to be elected at the time of election, the candidates of Mayor and Deputy Mayor of Pekanbaru should be able to pay attention to the rights of PwDs, approach and demonstrate their concern for the rights of PwDs.

\section{References}

[1] F. Brennan, D. B. Carr, and M. Cousins, "Pain management: a fundamental human right," Anesth. Analg., vol. 105, no. 1, 2007.

[2] I. Irmansyah, Y. A. Prasetyo, and H. Minas, "Human rights of persons with mental illness in Indonesia: more than legislation is needed," Int. J. Ment. Health Syst., vol. 3, no. 1, p. 14, 2009

[3] E. Aspinall and M. Mietzner, "Indonesian politics in 2014: Democracy's close call," Bulletin of Indonesian Economic Studies, vol. 50, no. 3, pp. 347-369, 2014.

[4] G. Maniagasi, M. F. Akbar, and Z. Nahruddin, "The Practice of Big-Man in The Local Political Dynamic: A Case Study Of Election Regency In Papua,” Eur. J. Res. Reflect. Arts Humanit., vol. 6, no. 2, 2018.

[5] S. Marzuki, "Peran Komisi Pemilihan Umum Dan Pengawas Pemilu Untuk Pemilu Yang Demokratis," J. Huk. Ius Quia Iustum, vol. 15, no. 3, pp. 493-412, 2008.

[6] D. Sukriono, "Menggagas Sistem Pemilihan Umum Di Indonesia," J. Konstitusi, vol. 2, no. 1, 2009. 